REGARDS

SUR LIECONOMIE ALLEMANDE

BULLETIN ECONOMIQUE DU CIRAC
Regards sur l'économie allemande

Bulletin économique du CIRAC

$69 \mid 2004$

Varia

\title{
Philosophie du droit
}

BUTZER Hermann (ed.), Wirtschaftlichkeit durch Organisations- und Verfahrensrecht / MATIS Klaus, Effizienz statt Gerechtigkeit? Auf der Suche nach den philosophischen Grundlagen der Ökonomischen Analyse des Rechts

\section{OpenEdition}

\section{Journals}

Édition électronique

URL : http://journals.openedition.org/rea/3523

DOI : 10.4000/rea.3523

ISBN : 978-2-8218-0834-8

ISSN : 1965-0787

Éditeur

CIRAC

Édition imprimée

Date de publication : 1 décembre 2004

ISSN : 1156-8992

\section{Référence électronique}

«Philosophie du droit », Regards sur l'économie allemande [En ligne], 69 | décembre 2004, mis en ligne

le 27 janvier 2009, consulté le 22 septembre 2020. URL : http://journals.openedition.org/rea/3523 ;

DOI : https://doi.org/10.4000/rea.3523

Ce document a été généré automatiquement le 22 septembre 2020.

(c) CIRAC 


\section{Philosophie du droit}

BUTZER Hermann (ed.), Wirtschaftlichkeit durch Organisations- und Verfahrensrecht / MATIS Klaus, Effizienz statt Gerechtigkeit? Auf der Suche nach den philosophischen Grundlagen der Ökonomischen Analyse des Rechts

\section{RÉFÉRENCE}

BUTZER Hermann (ed.), Wirtschaftlichkeit durch Organisations- und

Verfahrensrecht, Coll. Schriften zum öffentlichen Recht, vol. 964, Duncker \& Humblot, Berlin, 2004, 124 p.

MATIS Klaus, Effizienz statt Gerechtigkeit? Auf der Suche nach den

philosophischen Grundlagen der Ökonomischen Analyse des Rechts, Coll. Schriften zur Rechtstheorie, vol. 223, Duncker \& Humblot, Berlin, 2004, 220 p.

1 Dans sa thèse de philosophie du droit soutenue à l'Université de Zurich, K. Matis se penche sur la classique contradiction entre le concept d'efficience (approche économique) et celui de justice (droit public et social), cherchant à les concilier grâce à une approche interdisciplinaire qu'il dénomme une "théorie économique du droit». Sous l'angle pratique, le même questionnement est au cœur de la modernisation de l'administration et du développement de nouveaux modes de gouvernance publique, oscillant toujours entre impératifs économiques et justice (sociale), ainsi que le révèlent les Actes (Butzer) d'un symposium organisé en novembre 2003 sous la houlette notamment de W. Meyer, juge auprès de la Cour fédérale des Affaires sociales. (ib) 